\title{
Exploring Challenges in Practicing Instructional Leadership: Insights from Senior Secondary Principals
}

\author{
Abdul Rahim Abdul Rahman*, Lokman Mohd Tahir, Siti Nisrin Mohd Anis, Mohd Fadzli Ali \\ School of Education, Universiti Teknologi Malaysia, Skudai, 81310, Johor, Malaysia
}

Received June 26, 2020; Revised October 1, 2020; Accepted November 7, 2020

\section{Cite This Paper in the following Citation Styles}

(a): [1] Abdul Rahim Abdul Rahman, Lokman Mohd Tahir, Siti Nisrin Mohd Anis, Mohd Fadzli Ali , "Exploring Challenges in Practicing Instructional Leadership: Insights from Senior Secondary Principals," Universal Journal of Educational Research, Vol. 8, No. 11C, pp. 83 - 96, 2020. DOI: 10.13189/ujer.2020.082310.

(b): Abdul Rahim Abdul Rahman, Lokman Mohd Tahir, Siti Nisrin Mohd Anis, Mohd Fadzli Ali (2020). Exploring Challenges in Practicing Instructional Leadership: Insights from Senior Secondary Principals. Universal Journal of Educational Research, 8(11C), 83 - 96. DOI: 10.13189/ujer.2020.082310.

Copyright $\bigcirc 2020$ by authors, all rights reserved. Authors agree that this article remains permanently open access under the terms of the Creative Commons Attribution License 4.0 International License

\begin{abstract}
In ensuring schools achieving its excellence, the role of school leaders as instructional leaders is considered as relevant and officially documented in the Malaysian Education Blueprint (PPPM) 2013-2025. Previous studies have pointed out challenges faced by principals at various educational systems can delay the implementation of instructional leadership within school contexts. Even though there are extensive literatures on instructional leadership, there is a lack of studies that explored challenges faced by school leaders while implementing instructional leadership practices within the Malaysian schools. Therefore, this qualitative study was conducted with the purpose to explore challenges and obstacles faced by secondary principals while implementing their instructional leadership practice. A total of seven senior principals who had led their schools for at least five years were interviewed. The study revealed that the secondary principals faced two main challenges: the internal and external challenges. Externally, principals faced challenges from parents and teachers' negative attitudes and even less monitoring from the school's stakeholders. In terms of internal challenges, senior principals were challenged with their limited experience and knowledge on instructional leadership which lessen their roles as a resource person to all teachers and as instructional leaders. The findings of the study had led to the practical implications for the improvement of instructional leadership practices in Malaysian secondary schools' context.
\end{abstract}

Keywords Instructional Leadership, Senior Principals,
Instructional Leadership Practice

\section{Introduction}

In the era of globalisation of education, instructional leadership practices found to be relevant, suitable and have the highly believed contributed to the excellence of a school [1]. Evidently, instructional leadership has been highlighted by previous studies on its effectiveness to enhance students' achievements which later improving school's performance [2, 3, 4]. Thus, instructional leadership remained as the most studied model of leadership explored and examined in the area of school leadership and management [5;2]. In the context of Asian countries, instructional leadership was considered as emerging or currently proceeding being researched compared to other studies such as the United Kingdom, United States and European countries which had inspected the effectiveness of instructional leadership within their educational systems [6, 7]. Thus, the research on instructional leadership within Asian countries is considered as emerging [2, 8, 9]. Regardless of instructional leadership received wide attention among school leadership researcher, Bush (2014) [10] and Nguyen et al., (2017) [11] critically highlighted that most studies on instructional leadership presented are from the decentralised educational system and little is known on the practice of leadership related to centralised educational 
system. In addition, it is noted that instructional leadership must be examined from various cultures since differences in culture of every educational system have impacted how leadership was perceived and practiced by its principals [12].

In Malaysia, the introduction of Malaysian Education Development Plan (PPPM) 2013-2025 remarked a significant importance of instructional leadership when it was essentially emphasised within the policy alongside with distributed leadership [13]. Significantly, the main objective designated by Ministry of Education Malaysia (MOE) was to reduce the administrative workloads faced by principals; with assumption that principals are able to focus on their instructional leadership practices [14]. Through instructional leadership practice, the ministry has placed high hopes and empowered the school principals to improve the schools' academic performance as part of transformation and changing process of the overall system of education. According to $\mathrm{Ng}$ (2019) [15], the transformational process within the school's system is considered pertinent to improve the quality of education to align the purpose of local schooling in the $21^{\text {st }}$ Century demands on education. In addition, more developed countries such as South Korea and Japan also have slowly transforming their educational systems [15].

Thus, through this current educational policy, principals are expected to perform as an effective instructional leader with the assumption that every schools can be transformed into a high performing school [13]. In Malaysian context, instructional leadership has obtained the significant interest and attention among local researchers with the essential believe that the practice of instructional leadership is found central and pertinent to create schools that are improving and effective [16]. In this sense, principals are urged and expected to perform their significant role as instructional leader by continuing support to teachers' professionalism through organising programmes on teachers' professional development and competencies [20]. These effective instructional practices later will enhance students' academic achievements. According to Day, Gu and Sammons (2016) [3], the main purpose of instructional leadership is focus on the efforts and initiative to improve teaching and learning practice. Thus, most of the initiatives are focusing on instructional and classroom practice which later impacted students' performance [20].

\section{Statement of the Problem}

While practicing instructional leadership, principals are indeed facing some challenges which are able to slow the practice of instructional leadership in schools. Empirically, previous studies pointed on some reasons on instructional leadership challenges; lack of knowledge among principals [17; 20], and heavy workloads $[18 ; 19 ; 20]$. In fact, Hallinger and Murphy (2013) [20] affirmed that school principals are facing conflict and challenges while leading learning and within their daily practice for instructional purpose. In exploring the challenges, researchers in instructional leadership have pointed that novice principals are facing the stressful and strenuous experiences in practicing instructional leadership due to their lack of experiences, difficulties in managing their time, lack of understanding on the content of educational policy and even problems in managing their school's finance [20; 21; 22]. In this sense, Spilllane and Lee (2014) [23] highlighted that newly appointed principals' challenges in practicing their roles as instructional leaders which being described as stressful, shocking and overwhelming.

Admittedly, there are plentiful studies that examined on the role of principals as instructional leaders in various types of schools such as secondary, primary and even the technical and religious-based categorised schools. However, studies which explored on challenges and obstacles faced by principals while implementing instructional leadership are considered as under-researched, received little attention in Malaysian context of educational system. Many studies related to the principals' challenges are mainly from the western-based schools and least attention given on challenges faced by Malaysian principals. Therefore, additional study is needed to explore on the barriers and challenges faced by Malaysian secondary principals with the objective of preparing principals especially novice principals in countering the challenges that they faced as instructional leaders in their own schools.

In filling the gap which being addressed above which relates on principals' instructional leadership challenges, this qualitative study tried to explore on the challenges and barriers faced by secondary principals while executing the instructional leadership practices within their schools setting. From this study, we would like to explore and understand on the challenges that may slow the effectiveness process of instructional leadership within secondary schools in Malaysia. Thus, we investigate on the internal and external factors that have might slowed the principals' instructional leadership roles in schools.

\section{Research Questions}

Thus, this research was conducted to address the significant two major questions:

a. What are the internal barriers and challenges faced by secondary principals while practicing the instructional leadership at school?

b. What are the external barriers and challenges faced by secondary principals while practicing the instructional leadership at school?

Significantly, this study is an attempt to explore on the challenges that faced by principals while practicing their effective instructional leadership roles which received little attention within the instructional leadership framework. 
Second, this research will explore in-depth on the challenges that experienced by principals which least preferred within the instructional leadership literatures and references. Perhaps, from this study, it would help the existing and novice principals in finding solutions and strategies to address on challenges that principals faced while practicing instructional leadership. Third, this study will present some experiences that faced by principals which can be compared on the similarities and differences within other educational leadership systems and frameworks especially from the perspectives of western schools.

\section{Reviewing the Literature}

\subsection{Instructional Leadership: Definitions and Model}

In conceptualising the instructional leadership, there are initial definitions on instructional leadership by previous researchers. For instance, instructional leadership was defined as principals' initiatives and efforts with the purpose of enhancing student learning progress such as setting school vision, defining school goals, channelling resources needed for learning, implementing teacher supervision and evaluation, organising staff development programs and stimulating relationships and cooperation between teachers [24]. Primarily, the instructional leadership was being conceptualised as a personal characteristic of leadership practice which comprised behaviour, action and also involved practice that emphasised on the effectiveness on teaching and learning [25; 26].

Similarly, simple definition was provided by Glasman (1984) [27] as efforts taken by the school leaders to encourage and create a school's culture that emphasise on instructional practices which whereby enhance students' academic performance. As for other definition, instructional leadership was described as how principals emphasise on teaching and learning activities that undertaken to enhance teachers' productivity and conducive working environment which later improves students' performance [28; 29].

In their initial model, Hallinger and Murphy (1985) [29] have classified the instructional leadership practice into three main constructs, creating a school vision and mission, managing the instructional practice and lastly, creating a school's climate that emphasised on learning to improve teaching and learning in schools. In defining the school's mission and vision, principals are expected to play their effective roles in providing clear understanding to all teachers and staffs related to school's vision and mission mostly related to students' academic achievement and progress. Thus, Leithwood et al (2008) [30] listed principals' tasks such as articulating vision for learning, clarifying the standards of teachers and pupil performances, fostering teacher learning and development, and coaching teachers to attain success. In the second attribute which is related to managing the school's instructional programmes, school leaders should coordinate and manage the school's instruction and curriculum programmes in supporting students' learning experiences [31]. In this sense, all school leaders are expected to conduct high quality teaching and learning, tracking and monitoring on teachers' competencies and students' academic performance. To fulfill these tasks, principals should obtain assistance from their middle level leaders in dianogsing and monitoring teachers' competencies and students improvement on academic performance [32]. Third, in developing a positive culture, it is the duty of the principals in protecting and maximising the instructional time, motivating teachers and students through positive incentives for improvement [4].

Within the school leadership literature, the title of instructional leadership is considered as an evolving topic that received wide attention among school-based research over past 25 years [1]. However, the study of instructional leadership only received wide attention in the 1980's with the Hallinger and Murphy (1985)'s model of instructional leadership which is being studied and confirmed [33; 11]. $\mathrm{Ng}$ (2019) [15] later defined instructional leadership within two major views: the narrow and the boarder views. In the first, instructional leadership was defined as an instructional process which highly involved on the activities related to teaching and learning. Second, in the broader view, instructional leadership was re-conceptulised into a comprehensive framework which relates to academic performance such as creating a conducive climate for teaching and learning, instructional time scheduling and managing, teachers' competencies, and also other related activities and efforts on teaching and learning [15]. In general, instructional leadership is defined as strategies, activities and actions that being implemented by the school leadership in supporting, enforcing and ensuring the effective instructional activities related to teaching and learning in schools $[31 ; 2]$

In the year 2000's, instructional leadership has received wide attention among researchers in school-leadership context [11] which pointed on the importance of relationship and collaborative efforts between principals and teachers to secure the school's achievement [34; 35]. In this sense, most studies on instructional leadership have emphasised on the role of principals as a school leader that holds the central role in creating a school culture that promotes on the instructional practices. As such, principals are noted as the resource leaders for effetive instructional practice. In debating the role of principals within the instructional leadership framework, Ng (2019) [15] stressed that school principals remained as pertinent school leaders that are capable to create the school's conditions that emphasise on pedagogical activities and capacities, support and create more opportunities for teachers and students' innovation, allocate the financial and human 
resource and finally participate and ensure teachers participate in instructional whether individual or collective responsbility for the instructional improvement purpose. Thus, in terms of positive implication, it is stressed that the instructional leadership practice has benefited the school's performance which dealed with efforts and initiative of improving teaching and learning strategies [ $3 ; 25 ; 37 ; 38$ ].

\subsection{Instructional Leadership Practice in Malaysian Schools}

In Malaysian educational system, instructional leadership was placed pertinent as selected school-based leadership practice within Malaysian schools. Thus, it was mentioned within the Malaysian's Educational Blueprint 2013 - 2025 [39;14]. From the blueprint, it enhanced the practice of instructional leadership when principals in Malaysia are expected to play various their roles [40]. At the same time, principals should emphasise on instructional matters which include teaching and learning programmes, the school improvement processes and also teachers' professional development which later resulted in the school's academic improvement $[40 ; 41 ; 42]$. Through the implementation of instructional leadership in schools, the MOE hopes that there will be tremendous change within students' academic achievements [38]. Altough the ministry has placed a significant importance on instructional leadership to improve school-based leadership practice, studies on instructional leadership are considered as lacking and receive little attention [43] thus suggesting on more studies conducted on local instructional leadership practice.

Empirically, most studies on instructional leadership that were conducted locally are for the fulfilment for postgraduate theses and dissertations and mostly written in Bahasa Malaysia [5]. Although studies on instructional leadership are considered as limited, local researchers also have been researched on the practice of instructional leadership within their locality and based on their preferences. For example, Andi (2007) [44] surveyed 276 teachers on the practice on instructional leadership and its relationship with principals' sense of efficacy. Based on results, teachers perceived their principals have high level of self-efficacy in parallel with a strong emphasis on instructional leadership while performing school leadership functions. Based on principals' gender, female principals were indicated on having higher levels of instructional leadership practice and self-efficacy compared to the male principals. In Selangor, Latip (2007) [45] summarised that secondary principals had implemented and practiced all eleven instructional leadership functions followed by the enforcement of academic policies and the provision of incentives for learning. Finally, it can be seen that the practice of instructional leadership among principals in Malaysia placed great emphasis on the teaching and learning process by fostering a conducive school culture, i.e. the planning and success of the process is highly expected to achieve the desired goals and vision.

Recently, in 2019, Ghavifekr, Radwan and Velarde (2019) [38] had examined the practice of instructional leadership in Malaysian primary schools. Thus, a total 105 teachers were responded to the Principal Instructional Management Rating Scale (PIMRS) questionnaire. Based on findings, teachers perceived moderately on principals' tasks on defining the school's mission and managing their instructional programmes. However, teachers felt least satisfied with principals' role in creating and promoting the school's positive climate. From the perspective of teachers throughout Malaysia which is devided from the southern, northern, eastern, western and central zones, Abdullah et al (2019) [46] conducted a nationwide study on secondary middle managers' instructional practice based teachers' perspectives. Findings revealed that principals and middle school leaders remained as instructional leaders in schools. Findings also disclosed that principals were seen as least delegated and empowered their instructional duties to their middle managers. In fact, they were not given the full authority to practice their roles as an instructional leader. Similarly, Hassan, Ahmad and Boon (2019) (68) affirmed that the practice of instructional leadership has strong influence on teachers' professional learning communities in most schools in southern zone of Malaysia.

Earlier, Harris et al (2017) [5] summarised that primary school principals in Malaysian played their essential role as instructional leaders and at the same time had clear understanding of their functions and responsibilities and effective instructional leaders. Similarly, Ghavifekir (2015) [47] studied the practice of instructional leadership of principals from the technical and vocational schools in Kuala Lumpur which pointed out on the frequent practice of principals related to (a) professional leadership; (b) shared mission and clear goals; (c) continuous monitoring of teachers' progress; and (d) professional growth of the teachers. From Mustafa et al (2015)'s [48] study, teachers from schools in Pahang revealed that there is a relationship between instructional leadership practice with teachers commitment which indicated on the pertinent role of principals' instructional leadership towards teachers' growth and commitment towards their schools.

In general, many studies in instructional leadership focus on the achievement of vision, teaching and learning activities as well as a conducive teaching and learning climate. Based on past literature, it can be concluded that there is a strong association between principals' instructional leadership practices on students' academic improvement which later resulted in school's improvement and academic excellence. In conclusion, instructional leadership practices place emphasis on student achievement in the academic field, formulate and strengthen teaching strategies, provide and maintain a conducive environment in the school, regularly assess 
students’ academic achievement.

\subsection{Challenges in Practicing Instructional Leadership in Schools}

While implementing their roles as instructional leaders, principals indeed faced some challenges, barriers and obstacles that might halted or slowed their instructional improvements. As pointed by Scott (2017) [49], principals faced some challenges while practicing instructional leadership such as lack of funding and resources, high turnover of teachers and lack of educational resources. Earlier, Hallinger and Murphy (2013) [20] summarised on challenges faced by principals such as heavy workload, lack of knowledge to lead their schools, busy schedules, and the school structures which have many layers have provided difficulties for principals to manage the instructional programmes and coordinate the school's curiculum.

In conceptualising principals' challenges, the barriers are categorised into two major elements: the internal and the external challenges. Internally, principals are facing challenges which are related to their own weakness such as lack of knowledge and skills to be effective instructional leaders, and heavy workloads are some of the examples for internal challenges. Externally, resistance from teachers on their changes and improvement on instructional competencies and professional development are the notable challenge faced by principals. In addition, lack of support from parents is also another challenge faced by principals while practicing the instructional leadership.

Empirically, there are reasons of least instructional leadership practice by principals which are derived from their heavy workloads on administrative matters in schools [46; 20]. In this sense, principals spent most of their time handling their schools' disciplinary problems, paperwork, communication via telephone or internet which provided their least time for effective instructional practice [18; 19]. In addition, principals are noted as a source of reason for not emphasising and practicing instructional leadership which consequently forms principals' weakness in formulating strategies and goals, weakness in communication and having inefficient management [50]. Another notable barrier is lack of skills and training and considered as inexperience related to instructional leadership practice especially on how to perform their roles effectively [20]. This is happened to mostly to novice or newly appointed principals who have limited experiences, knowledge and skills on how to be effective instructional leaders in schools [17].

Similarly, previous studies also attested that stress in managing curriculum due to their heavy workload [51], lack of information, teachers and staffs who rejected the school's change and who felt comfortable with the existing situation [52] are challenges faced by principals as effective instructional leaders. In addition, principals had to perform various urgent tasks such as attending meetings, meeting parents and seeing damage in the school grounds. This situation has indicated principals with limited their time to pay attention to the practice of as effective instructional leaders [53].

\section{Methodology}

In selecting the design for this study, it is decided that qualitative case study which is undertaken to investigate the challenges and barriers in local public secondary schools studied. The decision on selecting the case study is based on the reason that case study is able to provide in-depth situation that illustrates the real life and unpacks the phenomena which are in the school practice [54; 67]. Through qualitative case study approach, data that were obtained from this study are detailed and extensive especially when studying about people together with their standpoints or insights [55]. As suggested, a multiple case study was chosen since the study involved seven senior principals from seven schools which consisted of interviews session with selected senior principals who had been practicing their instructional leadership in many years as instructional leaders. While practicing instructional leadership, senior principals also noted and shared that they also faced some challenges, barriers and obstacles that might slowed or distracted the instructional leadership effectiveness. Through interviews with senior principals, it is believed more accurate and indigenous data on instructional leadership challenges will be obtained based on opinion that the school leadership practice is highly sensitive to its surrounding contexts [25].

\subsection{Sampling}

In this study, a total of seven senior principals were interviewed and this paper presented their views of senior principals regarding the challenges that they anticipated while practicing instructional leadership. The senior principals who had been elected must have served for at least five years. For the sampling reason, a purpose sampling method was used in this study to represent the public secondary schools which later enable the exploration of challenges and obstacles of instructional leadership practice from various settings [56].

The demographics distribution of purposive selected senior principal includes their age, gender, academic qualification which includes their National Professional Qualification for Headship (NPQH)/ National Professional Qualification for Educational Leaders (NPQEL) and experiences as principals are presented in Table 1 . The reason of selecting only senior principals is based on reasons that senior principals have been practicing instructional leadership and highly emphasised on teaching and learning. Second, only senior principals have wide experiences in encountering various challenges while implementing instructional leadership in their schools. 
Table 1. Demographics of senior principals

\begin{tabular}{|c|c|c|c|c|c|}
\hline Numbers & $\begin{array}{c}\text { Participants' } \\
\text { identity codes }\end{array}$ & Age & Gender & Academic qualifications & Experience as principals \\
\hline Principal 1 & PK 01 & 57 & Women & $\begin{array}{c}\text { Bachelor } \\
\text { NPQH }\end{array}$ & $\begin{array}{c}\text { Bachelor } \\
\text { Master } \\
\text { NPQEL }\end{array}$ \\
\hline Principal 2 & PK 02 & 54 & Men years \\
\hline Principal 3 & PK 03 & 53 & Men & $\begin{array}{c}\text { Bachelor } \\
\text { Master } \\
\text { NPQEL }\end{array}$ & 8 years \\
\hline Principal 4 & PK 04 & 56 & Men & $\begin{array}{c}\text { Bachelor } \\
\text { NPQH }\end{array}$ \\
\hline Principal 5 & PK 05 & 56 & Women & $\begin{array}{c}\text { Bachelor } \\
\text { Master } \\
\text { NPQH }\end{array}$ & 8 years \\
\hline Principal 6 & PK 06 & 51 & Women & $\begin{array}{c}\text { Bachelor } \\
\text { Master } \\
\text { NPQEL }\end{array}$ \\
\hline Principal 7 & PK 07 & 56 & Men & $\begin{array}{c}\text { Bachelor } \\
\text { Master }\end{array}$ & 5 years \\
\hline
\end{tabular}

Based on Table 1, three selected senior principals are women principals while other four are male principals. In terms of their academic qualifications, all of them are graduates from their local mandatory leadership preparation programmes whether the NPQH/NPQEL. From the seven principals, only two principals are bachelor degree holders while another five principals obtained their master degree qualifications mostly in educational administration. Based on principals' years of experience, a principal has five years of experience as principal, one principal has nine years of experience, one principal has 10 years of experience as principal, two principals have six years of experience as principals, and lastly two principals have eight years of experience as principals.

\subsection{Interviewing Process}

For the collection of interview data, the instrument used consisted of semi-structured interview's protocol. This protocol was chosen to be used in order to obtain the relevant feedback on the obstacles faced by principals while implementing instructional leadership in their respective schools. In this sense, Gray (2009) [57] and Fraenkel and Wallen (2006) [58] agree that semi-structured interviews can help researchers investigate in more detail the answers given by study participants. The interview items presented are (1) What are the obstacles you face when implementing instructional leadership in your own school; (2) How do you classify these barriers into some key themes? Before the actual study was conducted, the researchers conducted a pilot study with two principals.

In the first meeting, researchers and principals discussed the setting of the date and time of the interview to be conducted. Principals were also given consent forms as study participants and interview protocols. They were also briefed on their rights as participants in the study and the confidentiality of this interview. All interviews were conducted in Malay language. These interviews were recorded and transcribed for the purpose of data analysis with the permission of all principals. These interviews were recorded using digital audio recorders and then analysed manually. Before starting the interview session, researchers have applied the suggestion from Johnson and Christensen (2014) [59] that is to start informal conversations first to build relationships before the actual interview is conducted. The duration of the interview that took place lasted between 50 to 60 minutes. After the interview session, the researchers made a transcript of the audio recording. The transcript of the interview data was then submitted to the selected principal to obtain confirmation and make improvements in the event of any data omissions.

\subsection{Data Analysis}

To analyse the interview data, several processes which suggested by Braun and Clarke (2006) [60] have been implemented which consist of organising, building themes, evaluating data and drawing conclusions from the interviews data. In this sense, Creswell (2009) supported the opinions by emphasising that interviews data need to be analysed or undergone a few processes which are organising, describing and building themes, reporting findings, interpreting findings and finally, verifying the accuracy of findings. In analysing interview data, the process commenced with transferring data from audio to texts. In the process, all verbatim which were obtained from seven series of interviews were transferred into texts. In the process of transcribing these interview data, researchers have used Atlas.ti7 software to simplify the management process. Upon completion of this transcript process, the researcher sent a copy of the transcript to the 
study participants for verification purposes. Verification has used the verification form provided along with the transcripts. The transcripts submitted for this verification have been corrected if there is an amendment from the principal interviewed.

In the second phase, all transcribed data, were read repeatedly to understand the overall meaning and ideas that the principals were trying to convey. Next, transcripts are compared to obtain the necessary information and meaning based on principals' statements [61]. In the following process, the transcripts were coded. The process of encoding this transcript is considered essential process in qualitative data analysis [62]. In the process, this transcript data has been reduced to certain meaningful codes. These codes will eventually be grouped into a theme.

Next, the data were categorised and subcategorised. The last process in the analysis is building a theme and description. In this phase, all codes that have been categorised broken down according to specific themes and descriptions. Description means data that contain information of study participants, places and events where the interview took place [61]. All themes obtained are considered as the relevant information to be used as the findings in a qualitative study.

\section{Findings}

From the series of interviews with seven senior principals, their verbatim were analysed manually and all emerging themes obtained were categorised into two major themes namely internal factors and external factors. Each subsequent theme is further broken down into several sub-themes. In the internal factors theme, the subthemes that are emerged are challenges based on principals' knowledge, attitudes, experiences and workload. As for the external factor themes, it is categorised as teachers, parents and stakeholders. Each category is further explained by several sub-categories. Detailed themes, categories and sub-categories related to barriers in instructional leadership practices are described in the following sections.

\subsection{The Internal Factors}

Based on the interviews, senior principals highlighted on internal factors that were emerged which capable to slow their roles as effective instructional leaders. Factors such as lack of experience to be instructional leaders, lack of knowledge on instructional leadership, the principals' negative attitudes are notable mentioned factors which being described as challenges that principals faced while practice instructional leadership.

\subsubsection{Lack of Experience}

From interview sessions with senior principals, four senior principals highlighted on the major challenge that principals faced which refer to lack of experience as instructional leaders. In interviews with them, both senior principals informed;

“...Ehmmm... do you agree if I say the obstacle comprised the internal and external? agree strongly... sometimes this principal is inexperienced and not good at dividing time ...” (PK02).

Similarly, three principals who were interviewed also raised on the issue of lack experience as an essential hurdle that existed when implementing instructional leadership practice in their schools. According to principals, lack of experience caused the principals failure to implement instructional leadership.

“...Lack of knowledge and ability to be an instructional leader is the essential reason for us as principals. Inexperienced school leaders will definitely a major problem, we are expected to be resource person to teachers and their effective instructional leader at the same time" (PK04).

\subsubsection{Least Understanding on the School's Culture}

Senior principals also shared other factors why principals sometimes did not perform well their effective roles as instructional leaders. Another factor mentioned was lack of understanding the school's culture. For principals, it is essential for them to understand the school's culture before proceed with any changes and innovation on instructional and learning programmes.

“...There are obstacles. Which is possible even here. The obstacle is how do we know that culture, right? Because our job is to promote a culture of learning, for example sometimes we are alone, we also see a lot of all aspects. Not just the school management aspect, right ...?” (PK03)

\subsubsection{Lack of Knowledge about Instructional Leadership}

Through interviews, principals argued that as instructional leaders, they should obtain much knowledge on instructional leadership to play their effective resource person for teachers. In contrast, if the principals considered themselves weak and ineffective due to lack of knowledge on instructional leadership, principals will face problems and issues in managing their instructional tasks and even programmes. As such, a senior principal shared his opinion;

" ...if knowledge about instructional leadership was considered as least... then the principals had difficulties to manage school ... because... it is not an easy thing ...you have to know everything and being expert to all teachers, in fact to all aspects ..." (PK02).

Likewise, opinions from a senior principal are being supported by two other senior principals. According to them, without strong command of knowledge in instructional leadership, it is considered hard or difficult for principals to implement and determine the instructional leadership practice in their schools. Both principals explained; 
“...That's right. Knowledge is important. Plague knowledge that makes culture. If there is no knowledge, how to promote the practice ...” (PK03).

“... lack of knowledge and ability to be an instructional leader an inexperienced leader..." (PK04).

“...Being a principal, really ... depends on yourself ... how you are, to develop your school...The most important thing is... your knowledge that is appropriate and necessary to manage the school...” (PK02).

\subsubsection{Principals’ Negative Attitudes}

Through interviews, senior principals also acknowledged that as principals, they need to think positively, support the Ministry of Education's policies and suggestions. In this sense, as principals, they need update themselves with recent educational policies introduced by the ministry. In addition, they also need to increase their skills and knowledge on instructional leadership. From interviews, senior principals shared on a few challenges and obstacles they encountered while practicing the instructional leadership which stems from the negative attitude of principals. According to senior principals, principals who do not take care about the instructional, lack of knowledge about leadership, instructional and less monitoring the aspects of instructional are issues, challenges and barriers in instructional leadership. The challenges were shared two senior principals during interview sessions;

" ...Because if we do not care, we do not say, one knowledge is less, then we do not care ..." (PK01).

" ...Maybe he, his knowledge is less than instructional. So he wants to monitor, he feels alone, maybe I made a mistake in my way, or maybe there is a better teacher than me. That is actually an obstacle..." (PK01).

" ...we take the example of monitoring PDP teachers...If there is no monitoring, teachers will teach students carelessly..." (PK04).

\subsection{The External Factors}

As for external factors, there are three themes emerged derived from series of interview sessions with senior principals. From the sessions, senior principals did mention on three central themes which are the attitudes of teachers and parents' negative attitudes and the schools' stakeholders' issues. In this study, the stakeholders are being referred as the District Education Office and the State Education Department.

\subsubsection{Teachers with Negative Attitudes}

When discussing on the external factors that challenged the principals' instructional leadership practice, almost all the senior principals did mention on teachers' negative attitudes as major challenge faced by principals while executing the instructional leadership practice. According to principals, teachers who are in their comfortable zone always showed their disinclination to change and even reject changes suggested by the school leaders. From interviews, principals did remark on a few categorised of teachers who always challenge principals' instructional leadership practice; teachers who lack of knowledge on instructional leadership, senior teachers who always reject on changes, and teachers who frequently involved in the outdoor and extracurricular activities are teachers that categorised as lessening the instructional leadership practice in schools.

Through interviews, principals also stressed on the attitude of teachers who do not care about instructional elements such as being late for class and did not conducted their instructional tasks;

"...we have a problem of teachers being late to class...also teachers who do not enter the class ..." (PK02).

In addition, another two principals also voiced on the issue of teachers who showed their reluctance and even mentioned that the school's changes processes are against the school's culture definitely challenged principals' roles as instructional leaders in schools. According to principals, some teachers did mention to them that they don't want to change or follow the new methods recommended by the principal because they felt comfortable with their traditional teaching strategies after so long implementing the approaches.

"...He still follows the old way...the teachers like to mention, this is our school tradition..." (PK01).

"...Sometimes they (teachers) are too comfortable..." (PK03)

In addition, a senior principal also voiced on the attitude of teachers who took advantage when principals were least monitored on their students' teaching and learning processes which sometimes causes problems in schools. A senior principal shared;

"...sometimes the teacher is also good. If he sees the boss (principal) does not see (monitor), they will take the opportunity, take the opportunity ...” (PK01).

As for a senior principal, he did think that the negative attitude of teachers who are not serious and lack of commitment are considered as obstacle to the implementation of instructional leadership.

"...teachers will teach students while they are lazy... when they are lazy, and not serious, students also learn like they don't want to..." (PK04).

\subsubsection{The Roles of Parents}

Apart from the teachers' negative attitudes, the issue of 
the uncommitted parents is also another mentioned challenge for senior principals while implementing their instructional leadership practice. Based on the interviews, the attitude of parents who are least committed to schools as well as parents who always leave their children's academic progress and matters to teachers and principals as another central issue faced by principals. Accordingly, principals did mention on the lack of monitoring from parents while their children are at home had also caused the instructional implementation into failure or decreased its effectiveness. Besides stressing on the attitude of parents who are less committed, senior principals did realise on some parents who lack of knowledge and even they don't know how to assist their children while at home also contributed to another challenge to success in the instructional leadership implementation.

"...my student's parents seem less committed to school ... " (PK02),

"...there are parents who did not perform their responsibilities and just let us to decide ...everything is depends on us ..." (PK04)

\subsubsection{The School's Stakeholders}

The third external factor which is being described as $\underline{\text { a }}$ hurdle faced by principals is the stakeholder issue. Accordingly, there are two main themes emerged which are the lack of monitoring from the official educational authorities and secondly, the frequency of principals attending courses and meetings which resulted in principals' absence from schools resulted in least improvement on instructional leadership practice. From interviews, a senior principal did highlight on the lack of monitoring from the educational authorities which led to some principals who did not implement their instructional leadership practice;

"...It seems that there is less monitoring from JPN with PPD...As for me, follow up and monitoring is very important. For instance, we were sent to courses, when we go back to school, it depends on us whether to implement or not, some will not do it, the JPN and PPD did not even check on us ...” (PK01).

As for another senior principal, the principal indicates on the number of principals who are absent from schools did not perform their instructional leadership tasks because they have least time to implement instructional leadership in the school.

"...there are also principals who tell me that they have to attend courses and workshop and received calls from PPD and JPN...for me, it is wrong. PPD and JPN officers sometimes seem not understand our duties..." (PK02).

Based on interviews with senior principals, it can be concluded that there are obstacles in the implementation of instructional leadership involving various parties, namely the attitude of teachers, parents who do not cooperate as well as the frequency of JPN and PPD calling principals for courses and seminars causing issues and obstacles while practicing instructional leadership. In addition, the internal aspects of the principals such as lack of knowledge, attitude of the principal and even lack of experience are delays caused in the implementation of instructional leadership in schools. The summary of the study findings is summarised in Table 2 below.

Table 2. Summary of themes and subthemes of challenges for principals' instructional leadership practice

\begin{tabular}{|c|c|c|}
\hline Themes & Category & Sub-Category \\
\hline \multirow{4}{*}{ Internal factors } & a) Knowledge & $\begin{array}{ll}- & \text { little, less } \\
\text { - } & \text { not enough } \\
\text { - } & \text { weak }\end{array}$ \\
\hline & b) Attitudes & $\begin{array}{ll} & \text { Do not know, do not care } \\
\text { - } & \text { Lack of confidence } \\
\text { - } & \text { lack of monitoring and regulation } \\
\text { - } & \text { lack of cooperation } \\
\end{array}$ \\
\hline & c) Experience & - $\quad$ less, a little \\
\hline & d) Workload & $\begin{array}{ll}\text { - } & \text { The real task } \\
\text { - } & \text { Not good at managing time } \\
\text { - } & \text { Not enough time-limited } \\
\text { - } & \text { Engaged in external tasks }\end{array}$ \\
\hline \multirow[t]{3}{*}{ External Factors } & a) Teachers & $\begin{array}{ll}\text { - } & \text { Lack of discipline } \\
\text { - } & \text { Comfort zone } \\
\text { - } & \text { Do not want to change } \\
\text { - } & \text { Take advantage } \\
\end{array}$ \\
\hline & b) Parents & - $\quad$ Lack of commitment \\
\hline & c) Stakeholders & $\begin{array}{ll}\text { - } & \text { Lack monitoring from JPN and PPD } \\
\text { - } & \text { Less follow-up } \\
\text { - } & \text { Involve principals in PPD and JPN activities }\end{array}$ \\
\hline
\end{tabular}




\section{Discussion}

Challenges, obstacle or barriers while implementing instructional leadership in school are often seen as the main hurdle to principals' effective roles as instructional leaders. In this sense, researchers believe that principals as school leaders must practice and implement the instructional leadership because they are the trusted school leaders in schools that have the accountabilities and responsibilities for the improvement, success and effectiveness of teaching and learning in schools [63]. However, within the implementation of instructional leadership, indeed there are challenges, barriers and obstacles within its implementation processes. In this sense, principals are expected by the educational authorities to practice the instructional leadership based on their creativity and innovation and at the same time encounter all the barriers and challenges that principals faced.

Through this qualitative interviews, seven senior principals had highlighted on two essential factors or challenges that may have resulted in least effectiveness and successful improvement on instructional leadership practice. According to senior principals, there are internal factors and external factors. In the external factors, principals did mention on negative attitudes of teachers, the lack of commitment of parents and least monitoring by the school's stakeholders. As for internal factors, senior principals did stress on principals' lack of knowledge to implement instructional leadership, principals' negative attitudes, and lack of experiences in executing the instructional leadership. In general, the findings of this study are corresponding with the findings of Azlin (2006)'s [18] study which also pointed out on the principals' internal factors such as lack of knowledge, attitudes, and experiences of principals which resulted in challenges for principals in performing their roles as effective instructional leaders. From Azlin (2006)'s [18] study, she reported that the in-experienced principals were found to be less pro-active, least creative and innovative in implementing their instructional leadership.

In terms of internal challenges, senior principals also commented on the lack of experience for some principals in practicing instructional leadership. To senior principals, having wide experiences in practicing and implementing instructional leadership is considered essential to determine their effectiveness as instructional leaders and being a resource person to all teachers. Therefore, senior principals did highlight on the importance for all principals to have wide experiences as instructional leaders to ensure the effectiveness of all instructional programmes at their own schools. In this sense, this study finding is similar with opinions from various researchers who pointed on the principals' lack of experience in implementing instructional leadership is considered as the major challenge and hurdle for principals to be acknowledged as instructional leader [17; 64]. In addition, senior principals also highlight on the lack of knowledge on instructional leadership remained as barrier to principals in implementing their instructional leadership practice in schools. As a result, the school principals became less confident to practice and adopted the instructional leadership when leading their schools. In this sense, as insisted by the Ministry of Education, principals should play their effective roles and resource person to teachers in guaranteeing on the successful implementation of instructional leadership in schools. From interview, senior principals did highlight on the importance and necessity for all public school principals to obtain the appropriate, in-depth and sufficient knowledge on instructional leadership to ensure their effective roles as instructional leaders. Otherwise, they will face problems, difficulties and issues in managing, promoting and implemeting their instructional leadership practice even ensuring the successful implementation of their instructional programmes at schools. Due to the lack of knowledge and experiences, principals are found to be less focused when facing complex tasks and encountering challenges while practicing their effective roles as instructional leaders.

The third challenge which also mentioned by senior principals is related to the negative attitudes of the school principals. According to senior principals, they admitted that there are principals who did not perform their duties as instructional leaders. In fact, those principals did not execute the instructional programmes which they should perform effectively. To senior principals, the negative attitudes of principals will result in the decline of the efficiency and growth of instructional leadership practice in schools. According to senior principals, as school and effective instructional leaders, they have to support the recent policies introduced by the Ministry of Education, updating their knowledge, disposition, and skills on instructional leadership. However, senior principals also told that there are principals who did not improve their knowledge, obtain least understanding on the concept, in fact, less monitoring on their instructional programmes. Hence, the negative attitudes of principals who did not monitor their instructional programmes will result in significant decline on students' academic performance. In this sense, principals are seen as least open to change and relatively passive in dealing with school instructional routines. As such, the findings are considered similar with suggestion by researchers in the instructional leadership practice $[48 ; 31 ; 2]$ that the school principals are the most significant person in determining the successful implementation and effectiveness of the instructional programmes at schools. In fact, within the Malaysian Educational Blueprint 2013 - 2025, the minitsry has informed on the pertinent role of the school principal as the resource person and implementer for the improvement of students' academic performance.

Despite the internal factors which are considered as challenges to principals’ instructional leadership practice, 
admitedly, there are other external challenges which are also faced by principals while excuting their instructional programmes. During interview, senior principals did mentioned on the challenges that they encountered while dealing with the essential roles of teachers, parents, and stakeholders which refer to the role of local educational authorities. In mentioning on the challenges faced by principals, senior principals did mention on there are teachers who have negative attitudes which are implicated with lessening the effectiveness of the school's instructional programmes. From interview, senior principals also comment on some teachers who are in their comfort zones who frequently reject or show their disinclination attitudes to all school's changes and transformational programmes. Thus, these teachers are considered as challenge since they are frequently against the newly introduced teaching approaches and strategies due to their feeling of comfortable within their traditional methods of teaching and learning.

Additionally, senior principals also mentioned on some teachers who also lack of knowledge on how to perform their duties on the instructional programmes assigned to them. In addition, teachers who are always frequently absent from schools due to their participations on the outdoor and extracurricular activities are also termed by senior principals as a group of teachers that had slowed the instructional leadership practice in their schools. In fact, there are some teachers who are always late for attending their classes and do not perform their instructional routines. Similarly, senior principals also commented on the attitude of some teachers who did not perform their designated teaching and learning programmes due to lack of monitoring from the school principals. Accordingly, lack of monitoring from principals will definitely leave teachers with their own teaching and learning strategies which are considered as an obstacle for the effective implementation of instructional leadership practice. As school leaders, principals have to perform their demanding duties in fulfilling various activities related to administrative and management matters such as scheduling, reporting, managing relationships with parents and the more complex community, dealing with unexpected student and teacher problems and also situations happen outside normal unexpected [65].

Apart from the teachers' negative attitudes, the issue of the uncommitted parents is also another mentioned challenge for principals while implementing their instructional leadership practice. Based on the interviews, senior principals' comments on the attitude of some parents who are indicated as least committed as well as leaving everything on their children academic matters to school. Based on senior principals' explanations, the neglecting attitudes of some parents are another challenge faced by principals when schools received least support from parents related to their children's academic progress and improvements are issues faced by principals. In fact, senior principals also mentioned on lack of monitoring from students' parents while at home; however, principals also noticed on some parents who least understand on how to help their children related to their academic matters. To principals, there are issues related to the positive collaboration between schools and parents which needs to be improved since teachers and principals have many instructional tasks to be complete; thus, they insisted on parents' support to monitor their children especially on the instructional tasks given to students.

During interviews, principals also talked about another central challenge faced by principals while performing their duties as instructional leaders. In this sense, principals commented on the role of local educational authorities which refers to the lack of monitoring from the local educational authorities' offices which resulted in lack of implementation by schools and principals related to the instructional programmes. To senior principals, they insisted on frequent monitoring from the local authorities to ensure on the effective implementation of instructional programmes by all schools from the local educational authorities' offices. Accordingly, senior principals also talked on the much empowerment given by the local educational offices whether to implement or not to practice on the instructional tasks given to schools. During interview session, senior principals also comment on the assigned tasks provided by local educational authorities which ask principals to attend some courses, workshops and meeting. Thus, some principals were noted to have least time in performing their instructional leadership tasks due to their busy schedules and meeting that they have to attend which to senior principals, that they have to spend most of their time at schools to ensure on the effective implementation of any instructional programmes at schools. According to Mestry (2017) [66], the school principal is currently facing new challenge, a more complex decision and additional responsibilities than ever before. The daily duties of principals in the school are filled with various administrative and management tasks such as obtaining resources, managing student discipline, resolving conflicts with parents and dealing with unexpected teacher and student problems.

\subsection{Implications and Recommendations}

From the findings of the study, there are some implications, suggestions and in fact recommendations for practice can be forward for the benefits of Malaysian public-school principals in practicing their instructional leadership. First, during interviews, principals did mention on their busy schedules which sometimes distracted them to play their effective roles as instructional leaders. According to principals, they were packed with administrative duties such as attending meeting and courses related to school and instructional improvements. Thus, due to their busy schedules with meetings and 
courses, these administrative activities resulted in principals' absence. Thus, principals have least time to monitor any instructional programmes and activities assigned. As for recommendation, the local educational authorities are advised to conduct or organise workshops, meetings and even courses during the school holidays so that principals can more focus on their roles as instructional leaders more effectively. With the high number of attendance at school, principals can implement more effective monitoring of teacher instructional assignments and are able to guide teachers or implement changes to teachers' negative attitudes.

Second, due to their busy schedules, principals need to empower their school leadership team to undertake the roles of instructional leaders. The school leadership team is consisted of the school's senior assistants, the heads of departments and subject's chairs. In this sense, principals need to delegate some instructional tasks to their senior leadership team to ensure that all instructional assignments are implemented although the school principals are away from their schools to attend meetings, workshops and even courses. With this approach, all instructional tasks will be executed with or without the existence of the school principals. In addition, it also will enhance teachers' capacities as instructional leaders through distributed and teacher leadership practice. At the same time, these distributed approaches will reduce or eliminate principals' heavy workload.

Based on the findings, to overcome the school principals who lack of experience and knowledge on instructional leadership, the local educational authorities have to conduct or organise more courses on instructional leadership especially during the school holidays to novice and aspiring principals in order to overcome the issue of lack of experience and knowledge on instructional leadership. In addition, the local educational authorities should emphasise on the concepts and approaches on instructional leadership within principals' leadership preparation courses such as the NPQEL to expose the aspiring and novice principals with knowledge, skills and disposition related to instructional leadership. As a result, it will definitely reduce the principals' issues and problems related to their lack of knowledge and experience in practicing their effective roles as instructional leaders in schools.

\subsection{Limitations of the Study}

Specifically, this study has some limitations that being acknowledged. First, from the generalisation aspect, the interview data is only limited based on the views and perspectives of the seven senior principals who are participated in this study who were secondary school principals. Through this study, senior principals have provided us with their standpoints, views and perspectives through series of interviews. Therefore, the findings of the study are considered quite difficult to obtain any generalisations to represent the whole perspectives of Malaysian principals. In this sense, we also question on the generalisation which sometimes has similarities and is contrasted with other types of schools such as primary, religious-based, high performing and cluster schools, private or international schools or may be technical and vocational types of school.

Second, as for the improvement of the study's design, it is encouraging to employ the mixed methods design in fulfilling the study's gap due to this study's limitations based on fully qualitative approach. From the mixed methods approach, the study will commence with a more number of principals who responded on items related to principals' challenges while performing their duties as instructional leaders from various perspectives; externally and internally. Following to the quantitative findings, interviewing and observation approaches can be implemented to have in-depth findings on the mentioned challenges from the quantitative data findings.

Third, this study only involves interviews with seven senior principals, to increase the validity of the study findings, quantitative methods can be proposed that is to increase the number of principals in order to increase the validity and reliability of the study. Fourth, this study is conducted in the category of national secondary schools, for future purposes, the study can be done in private schools, religious schools or vocational colleges that may have findings that are quite different from national secondary schools and less studied in the instructional leadership sides.

\section{REFERENCES}

[1] Hallinger, P. (2005). Instructional leadership and the school principals: a passing fancy that refuses to fade away. Leadership and Policy in Schools. 4(3): 221-240.

[2] Harris, A., Jones, M., Adams, D., \& Cheah, K. (2019). Instructional leadership in Malaysia: a review of the contemporary literature. School Leadership \& Management, 39 (1), $76-95$.

[3] Day, C., Gu, Q. \& Sammons, P. 2016. The impact of leadership on student outcomes: How successful school leaders use transformational and instructional strategies to make a difference. Educational Administration Quarterly, 52(2): 221-258.

[4] Hallinger, P., \& Hosseingholizadeh, R. (2019). Exploring instructional leadership in Iran: A mixed methods study of high- and low-performing principals. Educational Management Administration \& Leadership, 48 (4), 595616.

[5] Harris, A., Jones, M., Cheah, K., Devadason, E., \& Adams, D. (2017). Exploring principals' instructional leadership practices in Malaysia: insights and implications. Journal of Educational Administration, 55 (2), 207 - 221. 
[6] Hallinger, P., \& Walker, A. (2017). Leading learning in Asia-Emerging empirical insights from five societies. Journal of Educational Administration, 55(2), 130-146.

[7] Rigby, J. (2014). Three logics of instructional leadership. Educational Administration Quarterly, 50(4), 610-644.

[8] Hallinger, P. \& Chen, J. (2015). Review of research on educational leadership and management in Asia: A comparative analysis of research topics and methods, 1995-2012. Educational Management Administration \& Leadership 43(1): 5-27.

[9] Walker, A. and Hallinger, P. (2015). A synthesis of reviews of research on principal leadership in East Asia. Journal of Educational Administration, 53(4), 554-570.

[10] Bush, T. (2014). Instructional leadership in centralized contexts: rhetoric or reality?, Educational Management Administration \& Leadership, 42 (1), 3-5.

[11] Nguyen, D.T., Ng, D., \& Yap, P.S. (2017). Instructional leadership structure in Singapore: a co-existence of hierarchy and heterarchy. Journal of Educational Administration, 55 (2), 147-167.

[12] Zhao (2018). Understanding principal's instructional leadership: A theoretical and empirical analysis in China. Beijing: Beijing Normal University Publishing Group.

[13] Ministry of Education. 2012. Malaysia Education Blueprint 2013- 2025. Malaysia Retrieved from http://www.moe.gov.my/userfiles/file/PPP/Preliminary-Blu eprint-Eng.pdf

[14] Abdullah. J.B. (2012). Instructional leadership practice and attitudes towards changes among principals in secondary schools in Pahang. Unpublished PhD thesis, National University of Malaysia

[15] Ng, D.F.S. (2019). Instructional leadership. In Wong, B., Hairon, S., \& Ng. P.T. (eds.) School Leadership and Educational Change in Singapore (pp.7 - 30). Switzerland: Springer Nature.

[16] Sazali, Y., Rusmini, K.A., Abang Hut, A.E. \& Zamri, A. B. (2007). Relationship between instructional leadership with school effectiveness. Journal of Educational Management and Leadership, 17(2): 105-117.

[17] Wieczorek, D., \& Manard, C. (2018). Instructional leadership challenges and practices of novice principals in rural schools. Journal of Research in Rural Education, 34(2), $1-21$

[18] Azlin Mansor. (2006). Secondary school principals' management practice: a case study. Unpublished PhD thesis, National University of Malaysia.

[19] Maimunah Muda (2005). Situational leadership practices among secondary principals in Malaysia. Unpublished PhD thesis. National University of Malaysia.

[20] Hallinger. P., \& Murphy, J.F. (2013). Running out of time: finding the time and capacity to lead learning. NASSP Bulletin,

[21] Lee, K. A. (2015). The influence of instructional leadership on teachers' efficacy. Unpublished EdD dissertation. University of Kentucky.

[22] Nelson, S. W., de la Colina, M. G., \& Boone, M. D. (2008).
Lifeworld or systems world: What guides novice principals. Journal of Educational Administration, 46, 690-701.

[23] Spilllane, J., and Lee, L.C. (2014). Novice principals sense of ultimate responsibility: problems of practice in transitioning to the principal's office. Educational Administration Quarterly, 50(3), 431-446.

[24] Bevoise, W.D. (1984). Synthesis of research on the principals as instructional leader. Educational Leadership. 4(5): $14-20$

[25] Hallinger, P. (2016). Instructional leadership and school socio-economic status: a preliminary investigation. Paper presented at the Annual Meeting of the British Educational Leadership and Management Society (BELMAS), Chester, July 8-10.

[26] Mulford, B. (2008). The leadership challenge: Improving learning in schools (Australian Education Review No. 53). Camberwell, Victoria, Australia: Australian Council for Educational Research. Retrieved from http://www.acer.edu. au/research_reports/AER. html

[27] Glasman, N. (1984). Student Achievement and the school principals. Educational Evaluation and Policy Analysis. 6 (3): 283-296.

[28] Greenfield, W. D. (1985). Studies of the assistant principalship: toward new avenues of inquiry. Education and Urban Society, 18 (1): 7-27.

[29] Hallinger, P \& Murphy, J. (1985). Assessing the instructional leadership behavior of principals. Elementary School Journal. 86(2): 217-248.

[30] Leithwood, K., Harris, A. \& Hopkins, D. (2008). Seven strong claims about successful school leadership, School Leadership and Management, 28(1), 27-42.

[31] Hallinger, P. \& Wang, W.C. (2015) Assessing Instructional Leadership with the Principal Instructional Management Rating Scale. Dordrecht Netherlands: Springer.

[32] Ng, F. S. D., Nguyen, T. D., Wong, K. B. \& Choy, K. W. (2015a). A review of Singapore principals' leadership qualities, styles, and roles., Journal Of Educational Administration, 53 (4), 512-533.

[33] Southworth, G. (2002). Instructional leadership in schools: reflections and empirical evidence. School Leadership \& Management, 22 (1): 73-91.

[34] Robinson, V. M., Lloyd, C. A. \& Rowe, K. J. (2008). The impact of leadership on student outcomes: An analysis of the differential effects of leadership types. Educational Administration Quarterly, 44(5): 635-674.

[35] Marks, H.M. \& Printy, S. M. (2003). Principal leadership and school performance: Integrating transformational and instructional leadership. Educational Administration Quarterly 39(3): 370-397

[36] Hou, Y., Cui, Y., \& Zhang, D.H. (2019). Impact of instructional leadership on high school student academic achievement in China. Asia Pacific Education Review, 20:543-558.

[37] Le Fevre, D., \& Robinson, V.M.J. (2014). The interpersonal challenges of instructional leadership: Principals' effectiveness in conversations about performance issues. Educational Administration Quarterly, 51(1), 58 -95. 
[38] Ghavifekr, S., Radwan, O., \& Velarde, J. (2019). Teachers’ perceptions of principals' instructional leadership roles and practices. Jurnal Pendidikan Malaysia, 44(2), 72-83.

[39] Sim, Q, C. (2011). Instructional leadership among principals of secondary schools in Malaysia. International Research Journal. 2, 1784-1800.

[40] Ministry of Education. (2013). Malaysia Education Blueprint 2013-2025: Preliminary Report - Executive summary. Putrajaya: Kuala Lumpur.

[41] Ibrahim, K. A, Sani, M. I., \& Rosemawati, M (2017). Instructional leadership competency among school principal: An empirical study in Selangor. Journal of Educational Leadership, 2(3),1-14.

[42] Mohd Yusri, I. \& Aziz, A. (2015). Virtual leadership model and workplace wellness school leaders in Malaysia. Group communication as the mediator. Journal of Educational Leadership, 2(1), 1-10.

[43] Hallinger, P., Adams, D., Harris, A. \& Suzette Jones, M. (2018). Review of conceptual models and methodologies in research on principal instructional leadership in Malaysia: A case of knowledge construction in a developing society. Journal of Educational Administration, 56(1): 104-126.

[44] Andi Audryanah Md. Noor (2007). Principals’ instructional leadership and self-efficacy and its relationship with school's academic performance. Unpublished Master project. Universiti Teknologi Malaysia.

[45] Latip Muhammad (2007). The implementation of instructional leadership among principals. Paper presented at National Research Seminar at Batu Lintang Teaching Institute. Sarawak.

[46] Abdullah, A. G. K., Ali, A. J., Mydin, A., \& Amin, N. A. Z. (2019). Exploring capacity of middle managers as instructional leadership to lead transformations of teaching and learning in Malaysian high performing schools. International Journal Academic Research Business and Social Sciences, 9(3), 1132-1142.

[47] Ghavifekr, S., Ibrahim, M. S., Chellapan, K., Sukumaran, K., \& Subramaniam, A. (2015). Instructional leadership practices of principal in vocational and technical college: teachers' perception. Malaysian Online Journal of Educational Management 3(1), 48 - 67.

[48] Mustafa, N., M. Radzi, H. Jaafar, W. A. Rohana, and M. Nawawi. (2015). Principals' instructional leadership and teachers' commitment in three Mara junior science colleges (MRSM) in Pahang, Malaysia. Procedia - Social and Behavioral Sciences 191, 1848-1853.

[49] Scott, M. (2017). The challenges of instructional leadership in Manitoba first nations schools: an exploration of what principals have to say. Unpublished $\mathrm{PhD}$ thesis. The University of Manitoba.

[50] Beer, M. and Nohria, N. (2000). Cracking the code of change. Harvard Business Review 78(2) :133-141

[51] Bity Salwana Alias (2009). The analysis of principals' competencies, personal qualities, knowledge, skills and practice in managing schools. Unpublished $\mathrm{PhD}$ thesis, National University of Malaysia.

[52] Hazura. (2009). School principals as the agent of change at a school in Kelantan. Master project. Unpublished Master of Principalship. University of Malaya.

[53] Mohd Suhaimi Mohammed Ali \& Zaidatol Lope Pihie. (2007). Instructional leadership practices among principals at rural secondary schools. Paper presented at the $14^{\text {th }}$ National Seminar on Educational Management and Leadership. Institut Aminudin Baki. Genting Highlands.

[54] Liljenberg, M. (2016) Teacher leadership modes and practices in a Swedish context - a case study. School Leadership \& Management, 36(1), 21-40.

[55] Bogdan, R. C., \& Biklen, S. K. (2007). Qualitative research for education: An introduction to theory and methods. Boston, MA: Allyn \& Bacon.

[56] Yin, R.K. (2012). Case Study Research: Design and Methods (4th ed.). Thousand Oaks: Sage.

[57] Gray, D.E. (2009). Doing research in the real world $\left(2^{\text {nd }}\right.$ edition). London: Sage

[58] Fraenkel, J. R. \& Wallen, N. E. (2006). How to design and evaluate research in education $\left(6^{\text {th }}\right.$ edition). New York: McGraw-Hill.

[59] Johnson, B. \& Christensen. L. (2014). Educational research: quantitative, qualitative and mixed approaches ( $5^{\text {th }}$ Edition). Pearson.

[60] Braun, V., and Clarke, V. (2006). Using thematic analysis in psychology. Qualitative research in psychology. 3(2), 77 $-101$.

[61] Creswell, J. W. (2009). Research design: qualitative, quantitative and mixed methods approaches (third edition). Thousand Oaks, California: Sage.

[62] Creswell, J.W. (2012). Education research: planning, conducting and evaluating quantitative and qualitative research (4 ${ }^{\text {th }}$ Ed.). Boston: Pearson.

[63] Widhyanti Rosmaniar \& Shahril Charil Marzuki. (2016). Headmaster instructional leadership and organizational learning on the quality of madrasah and the quality of graduates the state madrasah aliyah at Jakarta capital region. Higher Education Studies, 6(1), 159 - 168.

[64] Norazlinda Saad. (2010). The influence of participation and attitudes in decision making towards teachers' commitments: Principals supports as the mediator. Unpublished EdD dissertation, Universiti Sains Malaysia.

[65] Oumer, W. (2014). Principal instructional leadership performances and influencing factors in secondary schools of Addis Ababa. Unpublished MA thesis. Ababa University

[66] Raj Majestry (2017). Empowering principals to lead and manage public schools effectively in the 21st century. South African Journal of Education, 37(1), 1- 11.

[67] Khan, A., Asmiran, S., Abdul Kadir, S, \& Basri, R. (2019) Principals' instructional leadership practices in Pakistan elementary schools: Perceptions and implications. Universal Journal of Educational Research, 8 (1A), 16 - 33.

[68] Hassan, R., Ahmad, J., \& Boon, Y. (2019). Instructional leadership practice and professional learning community in the Southern Zone of Malaysia. Universal Journal of Educational Research, 7 (12A), 42 - 50. 